\title{
HUBUNGAN AKREDITASI PUSKESMAS DENGAN KEPUASAN PASIEN DI PUSKESMAS KABUPATEN BANYUMAS
}

\author{
Eka Nofia Ningrum ${ }^{1}$, Etlidawati $^{2}$ \\ 1Fakultas Ilmu Kesehatan, 2Universitas Muhammadiyah Purwokerto, Jl. Letjen Soepardjo \\ Roestam PO. Box 229 Purwokerto 53181 \\ email: ekanofia87@gmail.com \\ 2Fakultas Ilmu Kesehatan, 2Universitas Muhammadiyah Purwokerto, Jl. Letjen Soepardjo \\ Roestam PO. Box 229 Purwokerto 53181 \\ email: etlidawati@ump.ac.id
}

Submitted : 02-04-2020, Reviewer:06-04-2020, Accepted: 07-04-2020

\begin{abstract}
Community Health Center (Puskesmas) must be periodically accredited at least once in three years. Accreditation status of Community Health Center (Puskesmas) can be affected by the availability and the completeness of health supply, facilities and infrastructure that support the health service itself. The purpose of this research to find out the correlation between the accreditation status of Community Health Center and the satisfaction of patients visiting Community Health Center in Banyumas Regency.

The research method used this was a quantitative research that used analytical survey design with cross sectional method. implemented at 4 Community Health Centers with different accreditation The cluster sampling technique used purposive sampling while the data were collected using questionnaire, and analyzed using Chi square test. Research result There were 61 respondents at the age of 17-25, 135 respondents were female, 116 respondents were SMA/SMK/MAN graduates, and 99 respondents were self employed. The result of chi-square test was p-value0.023 ( 0.05). Conclusion there was correlation between the accreditation status of Community Health Center and the satisfaction of patients visiting Community Health Center in Banyumas Regency.

Keywords: Accreditation, Community Health Center (Puskesmas), Patients Satisfaction.
\end{abstract}

\begin{abstract}
ABSTRAK
Puskesmas wajib untuk diakreditasi secara berkala paling sedikit tiga tahun sekali. Status akreditasi puskesmas dapat dipengaruhi oleh ketersediaan dan kelengkapan perbekalan kesehatan, sarana dan prasarana yang mendukung pelayanan kesehatan di puskesmas itu sendiri. Penelitian ini bertujuan mengetahui hubungan status akreditasi puskesmas dengan kepuasan pasien yang berkunjung di puskesmas Kabupaten Banyumas. Metode penelitian yang digunakan kuantitatif menggunakan desain survei analitik dengan metode cross sectional. Dilaksanakan di 4 puskesmas yang akreditasinya berbeda-beda. Teknik cluster sampling dengan cara Purposive sampling, pengambilan data dengan kuesioner, analisa data menggunakan uji Chi-square. Hasil penelitian sebagian besar responden berumur 17-25 tahun berjumlah 61 responden, berjenis kelamin perempuan berjumlah 135 responden, berpendidikan SMA/SMK/MAN berjumlah 116 responden, pekerjaan wiraswasta berjumlah 99 responden. Hasil uji chi square pvalue $=0,023(\leq 0,05)$. Kesimpulan terdapat hubungan antara status akreditasi puskesmas dengan kepuasan pasien yang berkunjung di puskesmas Kabupaten Banyumas.
\end{abstract}


Kata kunci: Akreditasi, Puskesmas, Kepuasan pasien.

\section{PENDAHULUAN}

Berdasarkan data yang di peroleh dari Dinas Kesehatan Republik Indonesia puskesmas berjumalah 9.993 dan terbagi atas puskesmas rawat inap berjumlah 3.623 dan non rawat inap berjumlah 6.370. Di Jawa Tengah puskesmas berjumlah 878 puskesmas dengan puskesmas terakreditasi berjumlah 868 (98,86\%) (Depkes RI, 2019). Puskesmas terakreditasi berdasarkan strata di Jawa Tengah akreditasi paripurna $0,8 \%$, akreditasi utama $15,03 \%$, akreditasi madya $63,76 \%$, dan akreditasi dasar 20,27\%. (Dinkes Jawa Tengah, 2019). Berdasarkan data yang di peroleh dari Dinas Kesehatan kabupaten Banyumas terdapat 39 puskesmas dengan tingkat akreditasi dasar berjumlah 11 (28\%), akreditasi madya berjumlah $24(61 \%)$, akreditasi utama berjumlah 4 (11\%). (Dinkes Banyumas, 2019).

Pada pasal 3 dan 4 dijelaskan bahwa Puskesmas wajib terakreditasi yang dapat dilakukan setiap 3 (tiga) tahun.Berdasarkan Peraturan Menteri Kesehatan Republik Indonesia Nomor 75 Tahun 2014 Pusat Kesehatan Masyarakat yang dimaksud Puskesmas adalah fasilitas pelayanan kesehatan yang menyelenggarakan upaya kesehatan masyarakat dan upaya kesehatan perseorangan tingkat pertama dengan lebih mengutamakan upaya promotif dan preventif untuk mencapai derajat kesehatan masyarakat yang setinggi-tingginya diwilayah kerjanya.

\section{METODE}

Jenis penelitian deskriptif kuantitatif dengan menggunakan metode cross sectional. Teknik sampling menggunakan teknik cluster sampling. Kriteria inklusi:Pasien yang berkunjung, pasien yang bersedia menjadi responden, pasien yang kooperatif dan komunikatif, pasien berumur > 17 tahun, pasien yang berkunjung ke 2 kali atau lebih. Kriteria ekslusi pasien emergency, pasien anak.Jumlah sampel yang diambil dalam penelitian ini yaitu 204 pasien yang memenuhi syarat penelitian. Tempat penelitian dilakukan di puskesmas Sumpiuh 1, Baturaden 1, Purwokerto Utara 1, Sokaraja 1. Instumen penelitian menggunakan kuesioner dan teknik pengumpulan data dengan cara pengisian kuesioner yang di dilakukan sendiri oleh responden.

\section{HASIL DAN PEMBAHASAN}

1. Karakteristik responden

Tabel 4.1 Karakteristik Responden Berdasarkan Umur, Jenis Kelamin, Pendidikan, dan Pekerjaan

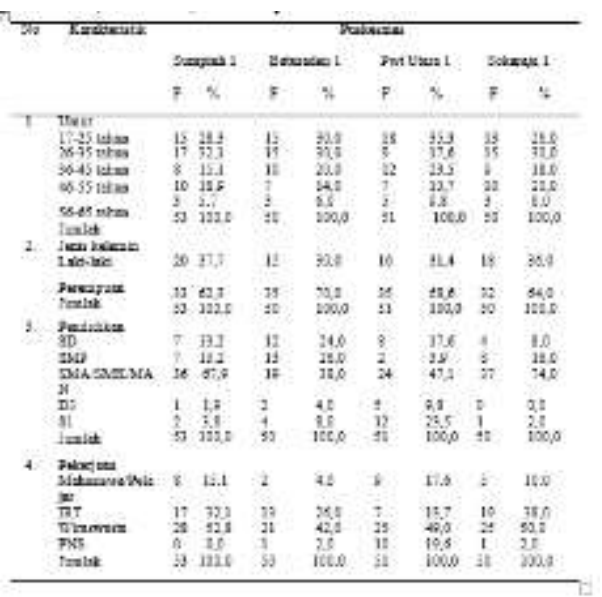

Berdasarkan tabel 4.1 diatas Puskesmas Sumpiuh1 53 responden sebagian besar responden berumur 26-35 tahun sebanyak 17 (32,1\%), Baturaden 150 responden sebagian besar responden 
berumur 17-25 tahun dan 26-35 tahun sebanyak masing-masing $15(30,0 \%)$, Purwokerto Utara 151 responden sebagian besar responden berumur 1725 tahun sebanyak 18 (35,3\%), Sokaraja 150 responden sebagian besar responden berumur 26-35 tahun sebanyak $13(26,0 \%)$, berdasarkan jenis kelamin mayoritas responden berjenis kelamin perempuan, puskesmas Sumpiuh 133 (62,3\%), Baturaden 135 (70,0\%), Purwokerto Utara 135 $(68,6 \%)$, Sokaraja $132 \quad(64,0)$. Berdasarkan tingkat pendidikan mayoritas responden berpendidikan SMA/SMK/MAN, puskesmas Sumpiuh 136 (67,9\%), Baturaden 119 (38,0\%), Purwokerto Utara $124 \quad(47,1 \%)$, Sokaraja 137 (74,0\%), berdasarkan pekerjaan mayoritas responden bekerja sebagai wiraswasta, Puskesmas Sumpiuh 128 (52,8\%), Baturaden 121 (42,0\%), Purwokerto Utara 125 (49,0\%), Sokaraja $125(50,0 \%)$.

\section{Frekuenasi Kepuasan Pasien}

Tabel 4.2 Distribusi frekuensi kepuasan pasien di Puskesmas Kabupaten Banyumas

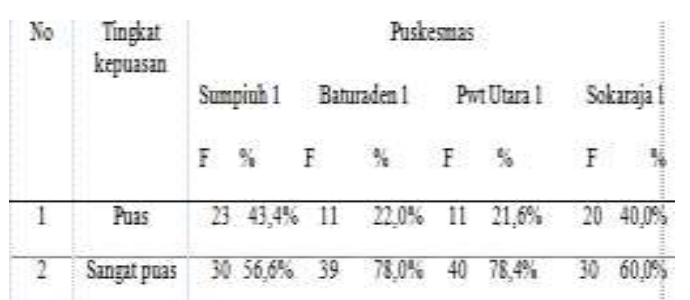

Berdasarkan tabel 4.2 dari 4 puskesmas dengan jumlah sebanyak 204 responden yang terbagi dalam Puskesmas Sumpiuh 1 responden puas sebanyak $23(43,4 \%)$, responden sangat puas sebanyak $30(56,6 \%)$, Baturaden 1 responden puas sebanyak $11(22,0 \%)$, sangat puas sebanyak $39 \quad(78,4 \%)$, Purwokerto Utara 1 responden puas sebanyak $11(21,6 \%)$, responden sangat puas sebanyak $40(78,4 \%)$, Sokaraja 1 responden puas sebanyak $20(40,0 \%)$, responden sangat puas sebanyak 30 $(60,0 \%)$.

Tabel 4.3 Distribusi frekuensi tingkat dan dimensi kepuasan pasien puskesmas Sumpiuh 1

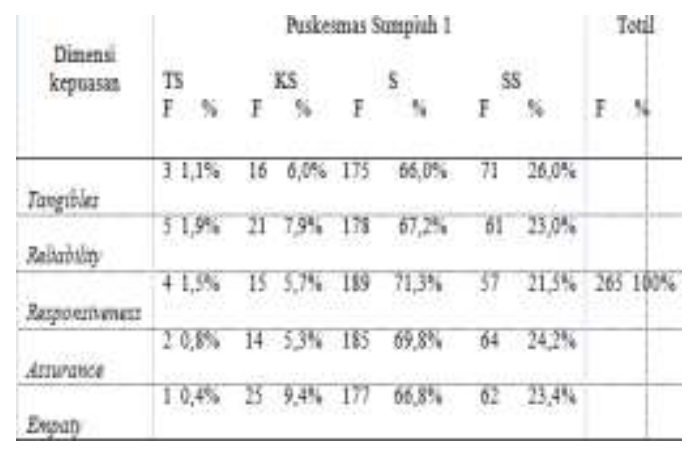

Tabel 4.3 dimensi kepuasan pasien tangibles sebagian besar dalam kategori setuju sebanyak 175 (66,0\%), Reliability sebagian besar dalam kategori setuju sebanyak 178 (67,2\%), Responsiveness sebagian besar dalam kategori setuju sebanyak 189 (71,3\%), Assurance sebagian besar dalam kategori setuju sebanyak 185 (69,8\%), Empaty sebagian besar dalam kategori setuju sebanyak 177 (66,8\%).

Tabel 4.4 Distribusi frekuensi tingkat dan dimensi kepuasan pasien puskesmas Baturaden 1 


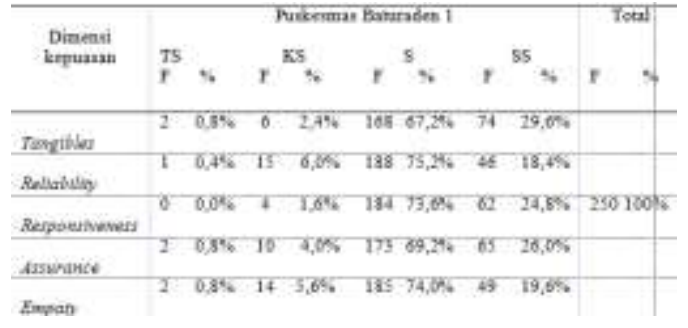

Tabel 4.4 dimensi kepuasan pasien tangibles sebagian besar dalam kategori setuju sebanyak 168 (67,2\%), Reliability sebagian besar dalam kategori setuju sebanyak 188 (75,2\%), Responsiveness sebagian besar dalam kategori setuju sebanyak 184 (73,6\%), Assurance sebagian besar dalam kategori setuju sebanyak $173(69,2 \%)$, Empaty sebagian besar dalam kategori setuju sebanyak $185(74,0 \%)$.

Tabel 4.5 Distribusi frekuensi tingkat dan dimensi kepuasan pasien puskesmas Purwokerto Utara1

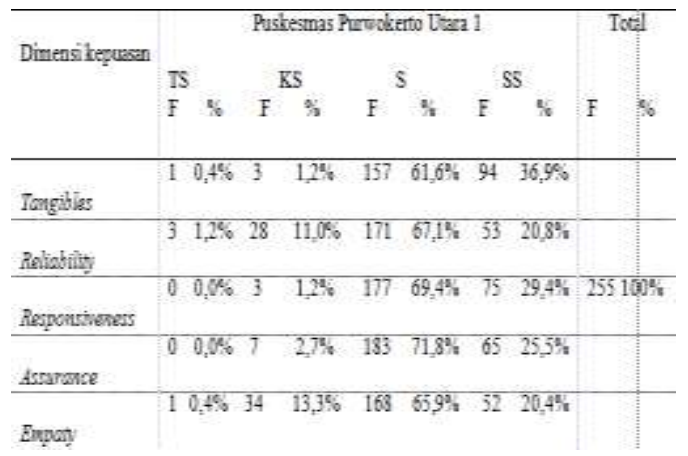

Tabel 4.5 dimensi kepuasan pasien tangibles sebagian besar dalam kategori setuju sebanyak 157 (61,6\%), Reliability sebagian besar dalam kategori setuju sebanyak $171(67,1 \%)$, Responsiveness sebagian besar dalam kategori setuju sebanyak $177(69,4 \%)$, Assurance sebagian besar dalam kategori setuju sebanyak 183 (71,8\%), Empaty sebagian besar dalam kategori setuju sebanyak $168(65,9 \%)$.

\section{Tabel 4.6 Distribusi frekuensi} tingkat dan dimensi kepuasan pasien puskesmas Sokaraja 1

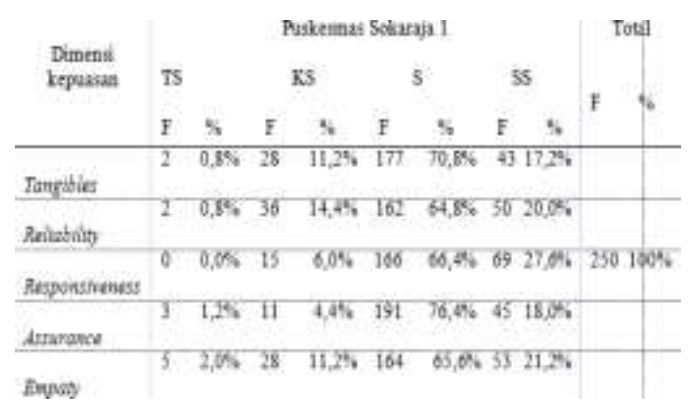

Tabel 4.6 dimensi kepuasan pasien tangibles sebagian besar dalam kategori setuju sebanyak 177 (70,8\%), Reliability sebagian besar dalam kategori setuju sebanyak 162 (64,8\%), Responsiveness sebagian besar dalam kategori setuju sebanyak 166 (66,4\%), Assurance sebagian besar dalam kategori setuju sebanyak 191 (76,4\%), Empaty sebagian besar dalam kategori setuju sebanyak $164(65,6 \%)$.

Tabel 4.7 Hubungan status akreditasi puskesmas dengan kepuasan pasien yang berkunjung di puskesmas Kabupaten Banyumas

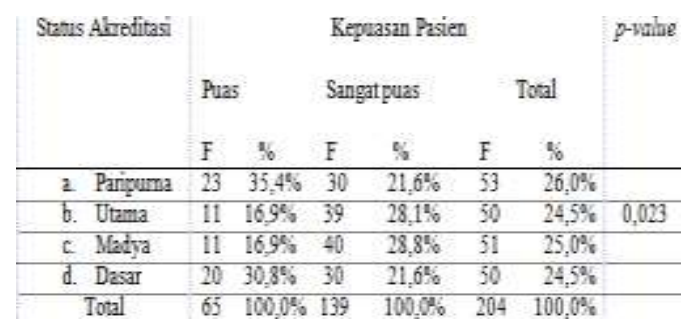


Berdasarkan tabel 4.7kepuasan pasien status akreditasi puskesmas paripurna ada 23 responden puas $(35,4 \%)$ dan 30 responden sangat puas $(21,6 \%)$, akreditasi utama ada 11 responden puas $(16,9 \%)$ dan 39 responden sangat puas $(28,1 \%)$, akreditasi madya ada 11 responden puas $(16,9 \%)$ dan 40 responden sangat puas (28,8\%), akreditasi dasar ada 20 responden puas $(30,8 \%)$ dan 30 responden sangat puas $(21,6 \%)$.Hasil uji statistik menggunakan uji chi-square nilai $\mathrm{p}=$ $0,023<0,05$, maka dengan demikian kedua variabel berhubungan.

\section{Pembahasan}

\section{a. Karakteristik Responden}

Berdasarkan hasil penelitian sebagian besar responden di Puskesmas Sumpiuh 1 berumur 26-35 tahun sebanyak 17(32,1\%), Baturaden1 berumur 17-25 tahun dan 26-35 tahun sebanyak masing-masing $15 \quad(30,0 \%)$, Purwokerto Utara 1 berumur 1725 tahun sebanyak 18 (35,3\%), dan Sokaraja 1 berumur 26-35 tahun sebanyak 15(30,0\%). Hal tersebut menunjukan bahwa semakin muda umur seseorang maka semakin kritis juga dalam berfikir. Hasil tersebut sejalan dengan hasil penelitian Rachmat (2019) bahwa umur responden terbesar adalah kelompok umur 18-30 tahun sebanyak 36 responden.

Berdasarkan hasil penelitian sebagian besar berjenis kelamin perempuan pada Puskesmas Sumpiuh 1 sebanyak 33 (62,3\%), Baturaden 1 sebanyak 35 (70,0\%), Purwokerto Utara 1 sebanyak $35(68,6 \%)$, Sokaraja 1 sebanyak $32(64,0 \%)$.
Hasil ini sejalan dengan penelitian Husnati (2016) yang meneliti tentang perbandingan kepuasan pasien Eks ASKES dan Non-ASKES di Puskemas pada Implementasi Jaminan Kesehatan Nasional, menyatakan sebagian besar responden berjenis kelamin perempuan sebnyak $126(70,5 \%)$ dan laki-laki sebanyak 50 responden $(29,5 \%)$.

Berdasarkan hasil penelitian sebagian besar pendidikan responden SMA/SMK/MAN yaitu pada Puskesmas Sumpiuh 1 sebanyak $36(67,9 \%)$, Baturaden 1 sebanyak $19 \quad(38,0 \%)$, Purwokerto Utara 1 sebanyak 24 $(47,1 \%)$, dan Sokaraja1 sebanyak $37 \quad$ (74,0\%). Menurut Notoatmodjo dalam Kaporina dkk (2013) menyatakan semakin tinggi tingkat pendidikan seseorang maka semakin mudah menerima informasi sehingga banyak pengetahuan yang dimiliki, Sebaliknya pendidikan yang kurang akan menghambat perkembangan sikap seseorang terhadap nilai-nilai yang baru diperkenalkan dalam pemberian pelayanan kesehatan.

Berdasarkan hasil penelitian sebagian besar pekerjaan responden wiraswasta yaitu pada Puskesmas Sumpiuh 1 sebanyak $28 \quad(52,8 \%), \quad$ Puskesmas Baturaden 1 sebanyak 21 (42,0\%), Purwokerto Utara 1 sebanyak 25 (49,0\%), dan Sokaraja 1 sebanyak 25(50,0\%). Menurut Notoatmodjo dalam Kaporina dkk (2013) bahwa pekerjaan berhubungan dengan aktivitas yangmerupakan sumber 
pendapatan. Pekerjaan dapat menggambarkan tingkat kehidupan seseorang karena dapat mempengaruhi sebagian aspek kehidupan seseorang termasuk dalam tuntutan pemeliharaan kesehatan.

\section{b. Kepuasan pasien}

Hasil penelitian sebagian besar responden di Puskemas Sumpiuh 1 puas sebanyak $23(35,4 \%)$ dan sangat puas $30 \quad(21,6 \%)$, Baturaden 1 responden puas sebanyak $11(22,0 \%)$ dan sangat puas sebanyak $39 \quad(78,4 \%)$, Purwokerto Utara 1 responden puas sebanyak $11(21,6 \%)$ dan sangat puas sebanyak 40 $(78,4 \%)$, Sokaraja 1 responden puas sebanyak $20(40,0 \%)$ dan sangat puas sebanyak 30 $(60,0 \%)$. Kepuasan pelayanan yang diperoleh didasarkan pada proses kinerja tenaga kesehatan berdasarkan prosedur, sikap ramah tamah tenaga kesehatan puskesmas Sumpiuh 1, Baturaden 1, Purwokerto Utara 1, Sokaraja 1 yang diberikan kepada pasien, menunjukan empati yang baik kepada pasien di Puskesmas Sumpiuh 1, Baturaden 1, Purwokerto Utara 1, Sokaraja 1 dan memberi arti tersendiri bagi pasien.

Dimensi Kepuasan Pasien antara lain sebagai berikut:

a) Dimensi Tangibles (Sarana prasarana)

Hasil penelitian sebagian besar responden dimensi Tangibles di puskesmas Sumpiuh 1 setuju175 (66,0\%), Baturaden 1168 (67,2\%), Purwokerto Utara 1157
(61,6\%), Sokaraja 1177 (70,8\%) . Dimensi Tangibles di puskesmas Sumpiuh 1, Baturaden 1, Purwokerto Utara 1, Sokaraja.

Hasil penelitian ini didukung dengan penelitian yang dilakukan olehAdhytyo (2013), yang menyatakan kualitas layanan yang meliputi kenyamanan atau kebersihan ruangan, kerapian petugas membuat pasien merasa puas. Pengaruh dimensi Tangibles dengan kepuasan pasien adalah semakin baik tampilan fisik maka kepuasan akan semakin baik dan juga sebaliknya.

b) Dimensi Reliability (Jasa)

Hasil penelitian sebagian besar responden dimensi Reliability di puskesmas Sumpiuh 1 setuju 178 (67,2\%), Baturaden 1188 $(75,2 \%)$, Purwokerto Utara 1 $171(67,1 \%)$, Sokaraja 1162 $(64,8 \%)$.

Hasil penelitian ini didukung dengan penelitian yang dilakukan oleh Adhytyo (2013) berjudul Reliabilitas Mempengaruhi Kepuasan Pasien Terhadap Pelayanan Kesehatan Di Salah Satu Puskesmas Kabupaten Ngawi, menytakan bahwa Reliability berpengaruh signifikan terhadap kepuasan pasien di Puskesmas Kedunggalar Kabupaten Ngawi.

c) Dimensi Responsiveness (Sikap)

Hasil penelitian sebagian besar responden pada dimensi kepuasan Responsiveness di 
puskesmas Sumpiuh 1 setuju 189 (71,3\%), Baturaden 1184 $(73,6 \%)$, Purwokerto Utara 1 $177(69,4 \%)$, Sokaraja 1166 $(66,4 \%)$.

Hasil ini membuktikan pada dimensi Responsiveness pelayanan di puskesmas Sumpiuh 1, Baturaden 1, Purwokerto Utara 1, Sokaraja 1 memuaskan hal tersebut dilihat dari hasil kuisioner sebagian besar kategori setuju karena petugas menangani keluhan pasien dengan cepat dan petugas bertindak cepat saat dibutuhkan pasien. Noreti (2016) mengatakan bahwa sikap dari seorang petugas pelayanan kesehatan merupakan salah satu faktor yang menentukan apakah pelayanan yang diberikan bermutu baik atau tidak,sehingga dengan sikap petugasyang ramah dan baik dalam memberikan pelayanan dapat menjadi penentu darikesembuhan seorang pasien,sebaliknya sikap petugas yang kasar dapat mengurangi kepuasan pasien terhadap pelayanan yang diterimanya.

d) Dimensi Assurance (Jaminan)

Hasil penelitian menunjukan dimensi Assurance di puskesmas Sumpiuh 1 sebagian besar puas sebanyak 185 (69,8\%), Baturaden 1 sebanyak $173 \quad(69,2 \%)$, Purwokerto Utara 1 sebanyak 173 (69,2\%), Sokaraja 1 sebanyak $191 \quad(76,4 \%)$. Dimensi Assurance di puskesmas Sumpiuh 1,
Baturaden 1, Purwokerto Utara 1, Sokaraja 1.

Penelitian Noreti (2016) terhadap variabel Assurance jaminan memberikan pengaruh yang positif dan signifikan terhadap kepuasan pasiendi Puskesmas Mendawai. Hal ini ditunjukan bahwa jaminan pelayanan kesehatan, keramahan, kesopanan dan kemampuan para dokter, perawat, tenaga medis lainnya, dan pegawai dalam melayani masyarakat memberikan kesan yang positif sehingga meningkatkan kepuasan masyarakat.

Penelitian Adhytyo (2013), menyatakan bahwa jaminan mempunyai hubungan terhadap kepuasan pasien. Pengaruh Assurance dengan kepuasan pasien adalah semakin baik pandangan terhadap jaminan maka kepuasan juga akan semakin baik. Dan jika pandangan terhadap jaminan rendah maka kepuasan juga akan rendah.

e) Dimensi Emphaty (Peduli)

Hasil penelitian dimensi Emphaty di puskesmas Sumpiuh 1 sebagian besar puas sebanyak 177 (66,8\%), Baturaden 1 sebanyak 185 (74,0\%), Purwokerto Utara 1 sebanyak 168 (65,9\%) , Sokaraja 1 sebanyak 164 $(65,6 \%)$.

Hasil ini membuktikan bahwa di puskesmas Sumpiuh 1, Baturaden 1, Purwokerto Utara 1, Sokaraja 1 memuaskan karena petugas mampu membuat simpatik 
pasien dan petugas yang ada di puskesmas Sumpiuh 1, Baturaden 1, Purwokerto Utara 1, Sokaraja 1 memberikan perhatian atau kepedulian terhadap pasien per individu. Hasil pengujian terhadap dimensi Emphaty memberikan pengaruh yang positif dan signifikan terhadap kepuasan pasien pada puskesmas Mendawai. Semakin baik persepsi pasien atau masyarakat terhadap kepedulian atau perhatian yang diberikan oleh penyedia jasa (Puskesmas Mendawai) maka semakin meningkat kepuasan yang dirasakan oleh masyarakat dan jika persepsi masyakat terhadap kepedulian atau perhatian yang diberikan penyedia jasa (Puskesmas Mendawai) rendah maka tingkat kepuasan akan menurun (Noreti, 2016).

c. Hubungan status akreditasi dengan kepuasan pasien yang kunjung di puskesmas Kabupaten Banyumas

Hasil Uji Chi Square nilai $p$ value di peroleh 0.023 yang lebih kecil dari $\alpha=0,05$, artinya Ho ditolak dan $\mathrm{Ha}$ diterima yang berarti secara statistik terdapat hubungan status akreditasi puskesmas dengan kepuasan pasien yang berkunjung di Puskesmas Kabupaten Banyumas diantaranya puskesmas Sumpiuh 1, Baturaden 1, Purwokerto Utara 1, Sokaraja 1.

Data kepuasan pasien akreditasi paripurna ada 23 responden puas $(35,4 \%)$ dan 30 responden sangat puas $(21,6 \%)$, utama ada 11 responden puas $(16,9 \%)$ dan 39 responden sangat puas $(28,1 \%)$, madya ada 11 responden puas $(16,9 \%)$ dan 40 responden sangat puas $(28,8 \%)$, dasar ada 20 responden puas $(30,8 \%)$ dan 30 responden sangat puas $(21,6 \%)$.

Dari hasil perhitungan puskemas Sumpiuh 1 didapatkan nilai rata-rata terendah pada kategori pertanyaan Assurance yaitu 3,00 pertanyaan nomor 5 yaitu "Memberi jaminan akan kesembuhan pasien" dalam hal tesebut berarti jaminan yang diberikan oleh puskesmas belum dapat dirasakan sepenuhnya oleh pasien yang berkunjung di puskesmas tersebut.

Dari hasil perhitungan puskesmas Baturaden 1 didapatkan nilai rata-rata terendah pada kategori pertanyaan Reliability yaitu 2,98 pertanyaan nomor 4 yaitu "Perawat segera menghubungi dokter mengenai obat dan makanan pasien" hal tersebut harus diperhatikan dari pihak tenaga kesehatan yang berkerja di puskesmas Baturaden 1.

Dari hasil perhitungan puskesmas Purwokerto Utara 1 didapatkan nilai rata-rata terendah pada kategori pertanyaan Empaty yaitu 2,82 pertanyaan nomor 2 yaitu "Perawat meluangkan waktu 
khusus untuk berkomunikasi dengan pasien" hal tesebut dapat menjadi perhatian khusus bagi puskesmas untuk lebih memperhatikan keluhankeluhan pasien.

Dari hasil perhitungan puskesmas Sokaraja 1 didapatkan nilai rata-rata terendah pada kategori pertanyaan Tangible yaitu 2,88 pertanyaan nomor 4 "Waktu untuk berkonsultasi keluarga pasien tidak terpenuhi" bentuk pelayanan bukti nyata seperti kecepatan dan ketanggapan pemberi pelayanan yang sesuai.

Menurut hasil penelitian dari Mirshanti (2018) bahwa tentang "Pengaruh Status Akreditasi Pusksmass, Faktor Sosial Ekonomi dan Jenis Asuransi Pasien terhadap Kualitas Pelayanan dan Kepuasan Pasien di Puskesmas" yang dilakukan pada 200 responden pada 4 (empat) puskesmas dengan status akreditasi yang berbeda di Kota Surakarta dan Kabupaten Karanganyar, sehingga dari hasil penelitian tersebut didapatkan bahwa kepuasan pasien dipengaruhi oleh akreditasi $(p=0,069)$.

Hasil penelitian ini sesuai dengan penelitian Andik (2018), di Puskesmas 1 Sokaraja yang menyatakan bahwa kondisi lingkungan terhadap kepuasan pasien mempunyai pengaruh yang signifikan positif terhadap kepuasan pasien sebesar 28 pasien puas diperoleh hasil uji chi square p-value 0,006 (< 0,05), kinerja petugas kesehatan dengan kepuasan pasien sebesar 29 pasien puas diperoleh hasil uji chi square p-value 0,007 $(<0,05)$, dan keceptan respon pelayanan dengan kepuasan pasien sebesar 27 pasien puas diperoleh hasil uji chi square p-value $0,004(<0,05)$.

\section{KESIMPULAN}

Berdasarkan hasil dan pembahasan penelitian diatas peneliti menyimpulkan sebagai berikut: puskesmas Sumpiuh 1 mayorias berusia 26-35 tahun, berjenis kelamin perempuan, pendidikan SMA/SMK/MAN, pekerjaan wiraswasta. Baturaden 1 mayoritas berusia 17-25 tahun dan 26-35, jenis kelamin perempuan, pendidikan SMA/SMK/MAN, pekerjaan wiraswasta. Purwokerto Utara mayoritas 1 berusia 17-25 tahun, berjenis kelamin perempuan, pendidikan SMA/SMK/MAN, pekerjaan wiraswasta. Sokaraja 1 mayorias berusia 26-35 tahun, berjenis kelamin perempuan, pendidikan SMA/SMK/MAN, pekerjaan wiraswasta.

\section{UCAPAN TERIMAKASIH}

1. Ns.Etlidawati S. Kep., M. Kep selaku pembimbing

2. Kris Linggardini, S. Kp., M. Kep selaku Penguji 1

3. Ns.Dyah Yulistika H, S. Kep., M. Kep selaku penguji 2

4. Seluruh Dosen dan staf Akademik Fakultas Ilmu Kesehatan Universitas Muhammadiyah Purwokerto 
5. Kedua orang tua dan orang terkasih yang telah memberikan dukungan dan do'a.

\section{DAFTAR PUSTAKA}

Adhytyo, R, D. \& Muliawati, R. (2013). Reliabilitas Mempengaruhi Kepuasan Pasien Terhadap Pelayanan Kesehatan Di Salah Satu Puskesmas Kabupaten Ngawi, Gaster. Jurnal Ilmu Kesehatan (2)

Departemen Kesehatan. (2019). Data Pusat Kesehatan Masyarakat Per Akhir Desember Tahun 2018.Jakarta.

Dinas Kesehatan Jawa Tengah. (2019). Buku Saku Kesehatan Tri Wulan 2.

Dinas Kesehatan Banyumas. (2019). Data Akreditasi Puskesmas Kabupaten Banyumas.

Husnati, (2016). Perbandingan Kepuasan Pasien Eks ASKES Dan Non-ASKES Di Puskesmas Pada Implementasi Jaminan Kesehatan Nasional. JSK 1 (3)

Kaporina, A., Setyawan, M.H. \& Novitasari, A. (2013). Gambaran Tingkat Kepuasan Pasien Terhadap Pelayanan Di Instalasi Rawat Inap Ruang B2 THT \& Kulit Kelamin RSUP Dr. Kariadi Semarang, Prosiding Konferensi Nasional PPNI Jawa Tengah
Mirshanti, Farahdila. Pengaruh Status Akreditasi Puskesmas, Faktor Sosial Ekonomi, dan Jenis Asuransi Pasien terhadap Kuslitas Pelayanan dan Kepuasan Pasien Di Puskesmas.

Diss.Universitas Sebelas Maret. 2018

Noreti. (2016). Analisis Pengaruh Kualitas Layanan Terhadap Kepuasan Pasien Pada Puskesmas Mendawai Kecamatan Arut Selatan Kabupaten Kotawaringin Barat. Tesis Universitas Terbuka Jakarta

Peraturan Menteri Kesehatan Nomor 75 Tahun 2014 tentang Pusat Kesehatan Masyarakat.

Primayoga Andik. (2018). Hubungan Kecepatan Respon Pelayanan, Kinerja Tenaga Kesehatan Dan Kondisi Lingkungan Dengan Kepuasan Pasien Rawat Jalan Puskesmas 1 Sokaraja. Fakultas Ilmu Kesehatan. Universitas Muhammadiyah Purwokerto

Rachmat, 2019. Hubungan Status Akreditasi Dengan Tingkat Kepuasan Pasien Di Puskesmas Tikala Baru Dan Puskesmas Tuminting Kota manado. 